\title{
POLÍTICAS PARA EDUCAÇÃO INFANTIL E A AGENDA E2030 NO BRASIL
}

\author{
Jani Alves da Silva Moreira (UEM)*
}

\section{RESUMO}

0 texto tem como objetivo analisar as atuais políticas preconizadas para a educação infantil no Brasil, no período 2015 a 2017. Apresenta resultados da análise de documentos internacionais para o contexto latino-americano, precisamente a partir da Agenda de Desenvolvimento Sustentável Pós-2015. Nesse contexto, os Estados membros da Organização das Nações Unidas (ONU) se comprometeram a programar e efetivar a Agenda E2030, pautando-se, sobretudo, no ODS4. Trata-se de uma pesquisa exploratória na qual se conclui uma categorização das principais políticas para a educação infantil que foram recorrentes nos enunciados dos documentos internacionais selecionados, oriundos de acordos internacionais e explicitados na forma de recomendações aos países signatários.

Palavras-chave: Políticas educacionais. Educação infantil. Agenda E2030. ODS4. Desenvolvimento sustentável.

\section{ABSTRACT}

\section{POLICIES FOR EARLY CHILDHOOD EDUCATION AND THE E2030 AGENDA IN BRAZIL}

The text aims to analyze the current policies recommended for the early childhood education in Brazil, in the period from 2015 to 2017. It presents results of the analysis of international documents for the Latin-American context, precisely since the Post-2015 Sustainable Development Agenda. In this context, the member States of United Nations (UN) committed themselves to plan and implement the E2030 Agenda, mainly guided by ODS4. It is an exploratory research, which is concluded with a categorization of the main policies for the early childhood education which were recurrent in the statements of the selected international documents, deriving from international agreements and explained in the form of recommendations to the signatory countries.

Keywords: Educational policies. Early childhood education. E2030 agenda. ODS4. Sustainable development.

\footnotetext{
* Doutora em Educação pela Universidade Estadual de Maringá (UEM). Docente Adjunto do Programa de Pós-Graduação em Educação (PPE) e do Departamento de Teoria e Prática da Educação (DTP), na Universidade Estadual de Maringá (UEM). Pós-doutoranda do Programa de Pós-Graduação em Educação da Universidade Federal do Paraná (UFPR) e Bolsista PNPD/ CAPES. E-mail: professorajani@hotmail.com
} 


\section{RESUMEN}

\section{POLÍTICAS PARA LA EDUCACIÓN INFANTIL Y LA AGENDA E2030 EN BRASIL}

El texto tiene como objetivo analizar las actuales políticas preconizadas para la educación infantil en Brasil, en el período 2015 a 2017. Presenta resultados del análisis de documentos internacionales para el contexto latinoamericano, precisamente a partir de la Agenda de Desarrollo Sostenible post-2015. En ese contexto, los Estados miembros de la Organización de las Naciones Unidas (ONU) se comprometieron a programar y hacer realidad la Agenda E2030, sobre todo, se basaron en el ODS4. Se trata de una investigación exploratoria en la que se concluye con una categorización de las principales políticas para la educación infantil que fueron recurrentes en los enunciados de los documentos internacionales seleccionados, oriundos de acuerdos internacionales y explicitados en forma de recomendaciones a los países signatarios.

Palabras clave: Políticas educativas. Educación infantil. Agenda E2030. ODS4. Desarrollo sostenible.

\section{Introdução}

A análise se assenta no cenário educacional brasileiro atual, do qual buscamos apreender alguns prenúncios do delineamento político para a Educação Infantil e apresentar as principais categorias políticas presentes na Agenda Educação 2030 (E2030) e no Objetivo do Desenvolvimento Sustentável 4 (ODS4), a fim de inquirir se essas recomendações estão presentes nas novas reformas em andamento para a Educação Infantil no país.

Em maio de 2015, no Fórum Mundial de Educação ocorrido em Incheon, Coreia do Sul, os 160 países participantes se comprometeram com a efetuação da agenda E2030, a qual abrange em específico para a Educação o objetivo número 4, denominado de ODS4 e expresso no documento resultante do Fórum, a Declaração de Incheon (ORGANIZAÇÃO DAS NAÇÕES UNIDAS PARA A EDUCAÇÃO, A CIÊNCIA E A CULTURA, 2015). A Organização das Nações Unidas para a Educação, a Ciência e a Cultura (Unesco) ficou como a responsável para liderar e coordenar a agenda política E2030 na América Latina e o Caribe (ORGANIZAÇÃO DAS NAÇÕES UNIDAS PARA A EDUCAÇÃO, A CIÊNCIA E A CULTURA, 2016).
Chefes de Estado, líderes governamentais e representantes da ONU e da sociedade civil se reuniram de 25 a 27 de setembro, em 2015, na 70aㅗ Sessão da Assembleia Geral das Nações Unidas, em reunião da Cúpula das Nações sobre o Desenvolvimento Sustentável 2015, que ocorreu na sede da ONU, em Nova Iorque. Durante a Cúpula foi adotada a Agenda 2030 e os Objetivos de Desenvolvimento Sustentável (ODS), que se refere a um conjunto "[...] formado pelos 17 Objetivos de Desenvolvimento Sustentável (ODS), que devem ser implementados por todos os países do mundo durante os próximos 15 anos, até 2030." (ORGANIZAÇÃO DAS NAÇÕES UNIDAS, 2017b, p. 1).

Após dois anos de lançamento da Agenda E2030, em 24 e 25 de janeiro de 2017, ocorreu em Buenos Aires a reunião da Cúpula dos ministros de educação latino-americanos e caribenhos, organizações internacionais e da sociedade civil. Na ocasião, discutiram as formas de alcançar os objetivos da Agenda E2030 para o alcance do Desenvolvimento Sustentável nos países. Em especial, essa foi a primeira reunião da cúpula regional que abordou com exclusividade o ODS4 da Agenda E2030, que se refere 
a "Assegurar a educação inclusiva, equitativa e de qualidade, e promover oportunidades de aprendizagem ao longo da vida para todas e todos" (ORGANIZAÇÃO DAS NAÇÕES UNIDAS, 2018, p. 1). A missão acordada pelos ministros de educação em Buenos Aires foi o delineamento de uma visão regional para a educação na América Latina e o Caribe até 2030, com o intuito de promover estratégias e programas nos países latino-americanos e caribenhos (ORGANIZAÇÃO DAS NAÇÕES UNIDAS, 2017a).

A análise crítica desenvolvida na pesquisa considera que existem mecanismos de regulação e controle no processo de cooperação internacional com o sistema ONU e suas organizações. Todavia, a compreensão do contexto global da Agenda E2030 e as determinações e diferenciações da política delineada no contexto local é um encaminhamento metodológico necessário para a compreensão de como se processa a definição da Agenda E2030 nos países.

O diagnóstico crítico e contextualizado se ancora na análise documental e tem como consideração que os enunciados presentes nos documentos internacionais e oficiais representam a empiria para a mediação e análise da categorização das políticas recomendadas, relacionando-as com o contexto global e o local. Cabe esclarecer que as reformas educacionais são marcadas por um complexo de resistência, enfrentamentos, contradições no qual os “[...] planos de educação e textos oficiais (leis, diretrizes, dispositivos jurídico-normativos) são apenas parte da construção de uma política, mas não são capazes de assegurar que será implementada tal como foi pensada" (SHIROMA, 2011, p. 16). Consideramos que as políticas são delineadas e acordadas em meio a uma trama de embates e interesses antagônicos tanto no campo local, como no nacional e no internacional.

Ao compreender as políticas para a Educação Infantil em meio ao contexto de reformas educacionais atuais, consideraremos que desde a década de 1990 ocorreu uma padronização nas reformas educativas da América Latina com ênfase às categorias políticas de descentralização (SOUZA, 2003), de focalização e de mercantilização da educação pública. Outro aspecto a considerar é que as mudanças políticas e econômicas geraram o que entendemos na atualidade como (anti)reformas na educação pública brasileira (MOREIRA, 2018).

0 propósito da pesquisa foi apreender essas mediações entre os contextos global e local a fim de elucidar e cotejar com as recomendações internacionais para a Educação Infantil no Brasil. Elencamos para a investigação três documentos internacionais, resultado de eventos ocorridos no período proposto, a saber: a) o Fórum Mundial de Educação, ocorrido em 21 de maio de 2015, na Coreia do Sul, cujo documento resultante foi a Declaração de Incheon; b) a 70aㅗ Sessão da Assembleia Geral das Nações Unidas, ocorrida em Nova York, de 28 de setembro a 06 de outubro de 2015 , no qual o Brasil assinou o documento intitulado Transformando Nosso Mundo: a Agenda 2030 para o Desenvolvimento Sustentável; c) a Reunião da Cúpula dos ministros de educação latino-americanos e caribenhos, que aconteceu nos dias 24 e 25 de janeiro de 2017, em Buenos Aires, do qual resultou a Declaração de Buenos Aires.

Com esse encaminhamento pretendemos categorizar as políticas recomendadas para o atendimento educacional à infância ${ }^{1}$ para, em

1 No estudo proposto consideramos infância os bebês, as crianças muito pequenas e pequenas, atendidas na Educação Infantil e elencadas na Lei de Diretrizes e Bases da Educação, Lei no 9.394 (BRASIL, 1996) como as pertencentes da faixa etária do nascimento aos cinco anos. Sob consultoria de Maria Carmem Silveira Barbosa, o Projeto de cooperação técnica MEC e UFRGS para a construção de orientações curriculares para a educação infantil apresenta em sua nota de rodapé 2 a terminologia bebês, crianças bem pequenas e crianças maiores. Justifica a autora que: "Tendo em vista que o Estatuto da Criança e do Adolescente (ECA) considera as pessoas de até 12 anos de idade incompletos como crianças, este documento, voltado para a educação de crianças de 0 a 6 anos utilizará uma nomenclatura diferenciada para destacar as especificidades requeridas pela faixa etária dos 0 a 3 anos. Assim, estamos compreendendo bebês como crianças de 0 a 18 meses; crianças bem pequenas como crianças entre 19 meses e 3 anos e 11 meses; crianças pequenas como crianças entre 4 anos e 6 anos e 11 meses. Reservamos a denominação de crianças maiores para as crianças entre 7 e 12 anos incompletos" (BRASIL, 2009, p. 5, grifo do autor). 
seguida, correlacionarmos com as políticas presentes na reforma educacional em andamento na Educação Infantil, no período de 2015 a 2017 no Brasil. Por meio de uma crítica contextualizada e da análise dos enunciados contidos nos documentos, intuimos compreender e evidenciar as orientações acordadas que estão sendo delineadas na agenda política atual para a Educação Infantil no Brasil.

Precisamente, destacamos uma categorização para as políticas enunciadas nos documentos internacionais selecionados e decorrentes dos acordos ocorridos nos eventos e explicitados na forma de documentos internacionais. Verificamos se no âmbito da Educação Infantil essas categorias políticas presentes nos documentos resultantes da Agenda E2030, nas Declarações de Incheon e de Buenos Aires era possível identificar a forma como essas categorias se apresentam na política atual para a Educação Infantil brasileira. Importante definir que a identificação das categorias auxilia a perceber o movimento e as definições da política para a Educação Infantil, sendo um instrumento necessário para interpretar o contexto de definição da Agenda E2030. Destaca Cury (1986, p. 21) que "[...] as categorias são conceitos básicos que pretendem refletir os aspectos gerais e essenciais do real, suas conexões e relações. Elas surgem da análise da multiplicidade dos fenômenos e pretendem um alto grau de generalidade".

Com a pesquisa realizada pretendeu-se responder: Quais as categorias políticas recomendadas pela E2030 e ODS4 para a Educação Infantil na América Latina e o Caribe? As políticas atuais para a Educação Infantil se referem às categorias políticas recomendadas pela E2030 e ODS4? Quais as implicações dessas categorias políticas e o que elas representam para o futuro da Educação Infantil brasileira?

Em um primeiro momento, situamos a Educação Infantil em seu contexto histórico, no qual abordamos os pressupostos históricos e políticos da Educação Infantil no Brasil a fim de compreendermos as permanências e mudan- ças no cenário político dessa etapa da educação básica e correlacionar com as orientações políticas produzidas no contexto atual, cabendo evidenciar o contexto de produção dos textos documentais. Apresentamos, na sequência, aspectos relacionados à coordenação da Unesco e agências parceiras ao propor uma agenda política para a Educação Infantil. Por último, elucidamos o cenário atual da política para essa primeira etapa da Educação Básica, precipuamente, a partir do pós-golpe parlamentar, jurídico e midiático ${ }^{2}$ no Brasil, no qual objetiva-se correlacionar com as categorias políticas da Agenda E2030 presentes na Declaração de Incheon (ORGANIZAÇÃO DAS NAÇÕES UNIDAS PARA A EDUCAÇÃO, A CIÊNCIA E A CULTURA, 2015), nas estratégias do ODS4 e propaladas na Declaração de Buenos Aires (ORGANIZAÇÃO DAS NAÇÕES UNIDAS PARA A EDUCAÇÃO, A CIÊNCIA E A CULTURA, 2017).

\section{Trajetória histórica e política na efetivação do Direito à Educação Infantil}

A história da Educação Infantil e da infância tem sido marcada por influxos e descontinuidades das políticas que delinearam as suas reformas educativas. Isso porque elementos das políticas e gestão da educação infantil pautaram-se em medidas decorrentes das demandas provocadas por transformações econômicas, sociais e políticas, derivados do modo como o capitalismo reestrutura as suas crises. 0 desafio precípuo tem sido estabelecer, manter e garantir aos bebês, às crianças muito pequenas e pequenas o direito à educação infantil por meio de "[...] políticas públicas que corroborem com a efetivação do direito à Educação Infantil

2 Para Alves (2017, p. 134), o processo de impeachment não possui fundamento jurídico, visto que nas análises do autor, a presidenta eleita Dilma Rousseff não cometeu crime de responsabilidade. Nesse sentido, o STF mais uma vez colaborou com o burlamento da Constituição de 1988. Assim, o golpe não seria apenas parlamentar, mas sim um golpe de natureza "jurídico, parlamentar e midiático", visto que obteve apoio destes outros dois setores. 
pública, laica, gratuita, inclusiva e de qualidade social para todas as crianças brasileiras de zero até seis anos" (MOVIMENTO INTERFÓRUNS DE EDUCAÇÃO INFANTIL DO BRASIL, 2018, p. 4).

Ao longo da história da educação infantil, um dos avanços mais significativos foi o reconhecimento estabelecido como a primeira etapa da Educação Básica, presente no artigo 208 da Constituição Federal de 1988, incisos I e IV (BRASIL, 1988), e no artigo 29 da atual LDB (BRASIL, 1996). Após essa efetivação, a luta tem sido para a construção de um Projeto Educacional para a Educação Infantil no país que promova de fato um atendimento educacional público, gratuito, laico, inclusivo e de qualidade social para todos os bebês e crianças, independente da classe social a qual pertencem, da etnia, do gênero ou da faixa etária que frequentam. Todavia, esse processo tem sido marcado por contradições e ambiguidades de propostas:

[...] a história da Educação Infantil nos mostra um processo contraditório em que a ambiguidade das propostas, desde sua origem e difusão, deixa vislumbrar as potencialidades existentes nas instituições educacionais para as crianças pequenas. Mas também tem sido a história do predomínio da concepção educacional assistencialista, preconceituosa em relação à pobreza descomprometida quanto à qualidade do atendimento. (KUHLMANN JÚNIOR, 1998, p. 202).

A educação infantil no Brasil tem suas raízes históricas demarcadas pelo assistencialismo. 0 atendimento às crianças foi distinto para as diferentes classes sociais: por um lado tínhamos assistência social aos filhos e filhas dos trabalhadores e das trabalhadoras; e para as crianças de famílias mais abastadas, uma oferta educacional (BOGATSCHOV; MOREIRA, 2009; KRAMER, 1987; KUHLMANN JÚNIOR, 2000; MOREIRA; LARA, 2012; RIZZINI, 1997).

Foi ao final do século XIX no Brasil que a criança foi concebida como um apoio para o empreendimento da moralização da pobreza e instrumento de ação do Estado, pois a degradação dessa classe era interpretada como um problema de ordem moral e social:
A infância, em meio a essas mudanças econômicas, anseio emancipatório do país, significou uma representação na perspectiva de moldá-la de acordo com o projeto que conduziria o Brasil ao seu ideal de nação, o futuro do país. Via-se a criança não mais como preocupação no âmbito privado da família e da igreja, mas uma questão de cunho social, de competência administrativa do Estado. (MOREIRA; LARA, 2012, p. 78).

Em contrapartida, Oliveira (1988) constatou que até $\mathrm{o}$ início do século $\mathrm{XX}$, o atendimento de crianças em creches inexistia no país. " 0 cuidado da criança pequena longe da mãe que trabalhava no meio rural se efetivava pela absorção natural" (OLIVEIRA, 1988, p. 44), e muitas crianças órfãs ou abandonadas, filhos bastardos originados em geral da exploração sexual da mulher negra e índia pelo senhor branco, foram adotados por famílias de fazendeiros para se tornarem criados e trabalhadores do campo. Outras crianças eram recolhidas nas rodas de expostos que existiam em algumas cidades, em instituições dirigidas por entidades religiosas ou filantrópicas. 0 objetivo desse atendimento às crianças que foram doadas a essas instituições era conduzi-las a um ofício quando adultas, promovendo assim, uma instrução. As instituições infantis como as "Creches, asilos e internatos eram vistos nas vilas existentes como instituições assemelhadas e destinadas a cuidar dos problemas dos pobres." (OLIVEIRA, 1988, p. 45).

A concepção de infância como um problema social refletia no anseio emancipatório com o futuro do país. Atribuiu-se à infância um valor econômico para o desenvolvimento da nação e, ao mesmo tempo, existiam os jardins de infância, de orientação froebeliana, como modelo em algumas instituições, a ser frequentado pelos filhos das famílias mais abastadas. Surgiu, assim, o setor privado da educação pré-escolar, que por meio de interesses em legitimar-se, utilizou-se do termo pedagógico para a divulgação mercadológica (BOGATSCHOV; MOREIRA, 2009; KRAMER, 1987; ROSEMBERG, 1989).

Nas três primeiras décadas de instauração da República no século XX, a marca do aten- 
dimento à criança pequena pautou-se nas concepções do movimento higienista do projeto civilizatório para o país. Esse movimento direcionado à infância, de acordo com Rizzini (1997), foi adotado por médicos e sanitaristas brasileiros. A proposta era a de investir na infância, por meio de uma atuação pautada no cientificismo e na filantropia, sobretudo ensinando as famílias a desenvolverem noções básicas de higiene e saúde, na acepção física e moral. Esse projeto geral pautou-se no saneamento e na puericultura como forma de divulgar os cuidados com a higiene infantil. Todavia, também se referia a uma perspectiva de controle racial, adotando princípios da eugenia, concepção racista que se propagou naquele período (KUHLMANN JÚNIOR, 1998).

A educação brasileira, a partir da primeira metade do século XX, obteve razoável influência do Movimento Eugênico no sentido de que o ambiente escolar poderia promover uma cultura para inibir ou nutrir o desenvolvimento por uma mudança na condição de uma população. Essa concepção foi um forte impulsor para políticas educacionais que se delinearam na época:

A ligação entre eugenia e escola teve efeitos contraditórios: por um lado, concentrou esforços, recursos e técnicas para ampliar a educação pública num molde que alcançava famílias que até então eram excluídas; mas por outro lado, os conceitos eugênicos que nortearam essa escola e ordenavam os alunos e professores dentro deles tendiam a definir pessoas que eram negras, ou vinham de meios pobres, como deficientes. Em lugar da exclusão, resultou numa moderna inclusão marginalizadora. (DÁVILLA, 2015, p. 5).

No contexto do imperialismo, de partilha do mundo, nomeadamente após as crises decorrentes da Primeira Guerra Mundial (1914-1918), do pós-Guerra (1920-1923), da Revolução Russa (1917), da crise econômica mundial de 1929, da Segunda Guerra Mundial (1939-1945), o Brasil e a América Latina vivenciaram um período de abalo pelo recuo do capital inglês e a penetração do capital imperialista norte-americano. Mudanças no mundo do trabalho exigiram espaços educativos e de cuidado para as crianças de mães e famílias que não tinham onde deixar os seus filhos e filhas. Por outro lado, a concepção de educação como instrução começava a se tracejar no século XX como necessária para o processo de industrialização e modernização do país.

Quanto ao atendimento à criança pequena, as mudanças provenientes da reconfiguração no ambiente familiar e os movimentos de luta por creche se intensificaram a partir da década de 1970 no Brasil, tendo suas raízes em fatores estruturais e conjunturais, evidenciando o problema do empobrecimento das camadas populares e a necessidade das mulheres trabalharem fora de suas próprias casas, para o complemento do orçamento doméstico. Gohn (2009, p. 29, grifo nosso) ressalta que foi a partir da década de 1980 que houve:

[...] um deslocamento do foco central do movimento de creches quanto à da reivindicação, antes centrada na figura da mãe, passando agora para a figura da criança. Isto nos explica a questão do caráter educativo dado aos equipamentos, e o tratamento das creches sob o ponto de vista da Educação - a educação infantil de 0 a 6 anos; e não mais como simples problema assistencial, como foi tratada nos anos 60 e 70.

Contradições e permanência das tendências assistencialistas e compensatórias ainda se mantiveram mesmo com a expansão das creches e com o deslocamento do foco central na figura da criança e sua educação. As orientações básicas das políticas favoráveis à creche e às pré-escolas como mecanismo compensatório do atendimento à pobreza ainda se vincularam aos programas de promoção social e ao trabalho materno. Na sua maioria eram desenvolvidas por entidades filantrópicas e religiosas, mesmo tendo sido permeadas de ações e atividades escolarizantes.

Outra problemática que se inscreve nas raízes históricas da Educação Infantil é a dualidade estrutural entre assistência e educação, sobre a qual Abramowicz (2002, p. 2) enfatiza que "[...] as pré-escolas designam escolas de 
crianças pequenas e de uma classe social com mais possibilidades econômicas, e as creches são os equipamentos destinados às crianças pobres e às classes populares".

Na década de 1980 vislumbraram-se tentativas de tornar a Pré-Escola como solução para os problemas da pobreza, uma concepção pautada na educação infantil como etapa preparatória para solucionar as altas taxas de reprovação no ensino de $1^{\mathrm{o}}$ grau. Essa proposta estava contida nos planos II e III dos Planos Setoriais de Educação e Cultura (PSEC), do Ministério da Educação, que passou a se ocupar da educação pré-escolar, nos períodos 1975-1979 e 19801985 (KUHLMANN JÚNIOR, 2000). Foi a partir do movimento de (re)democratização do país, na década de 1980, que entrou em discussão a Educação Infantil; distante de um caráter definido e educativo, desprovida de regulamentações e políticas específicas, passou a ser foco de discussão no âmbito da reforma educacional do país. Pode-se enfatizar que o novo contexto de reorganização e as novas definições políticas para a educação infantil significaram que o final do século XX no Brasil foi:

[...] um período marcado por reformas educacionais e mudanças substantivas na era da globalização econômica que configuraram em políticas de ordem neoliberal. Esse consenso ideológico transportou-se nas legislações específicas relacionadas ao atendimento à infância. Percebe-se uma ampliação para o atendimento à infância. (BOGATSCHOV; MOREIRA, 2009, p. 8).

Com a redemocratização do país e a aprovação da Constituição Federal de 1988 (BRASIL, 1988), o Estatuto da Criança e do Adolescente (ECA), Lei no 8.069 (BRASIL, 1990), e a Lei de Diretrizes e Bases da Educação, Lei no 9.394 (BRASIL, 1996) ocorreram efetivas mudanças para o estabelecimento da educação infantil como direito subjetivo da criança, assegurando 0 atendimento de crianças até seis $\operatorname{anos}^{3}$ na educação infantil em creches e pré-escolas (Art.

3 Salientamos que foi a partir da aprovação da Emenda Constitucional no 53, de 2006, que se alterou o inciso IV do Art 208: "IV - educação infantil, em creche e pré-escola, às crianças até 5 (cinco) anos de idade." (BRASIL, 2006a).
208, inciso IV da CF). O ECA (BRASIL, 1990) reitera os direitos já declarados na Constituição Federal de 1988 e no artigo 53 reafirma o direito da criança e do adolescente à educação, com vistas ao desenvolvimento pessoal pleno, ao exercício da cidadania e qualificação para o trabalho e assegura, entre outros, o direito ao acesso e permanência em escola pública e gratuita perto de seu domicílio (Art. 53, inciso V). No artigo 54, inciso 4을 assegura à criança de zero a cinco anos ${ }^{4}$ de idade o direito de atendimento em creche e pré-escola.

Com a atual LDB tivemos o avanço marcado pela definição da educação infantil como a primeira etapa da educação básica, cuja finalidade é o desenvolvimento integral da criança de até cinco anos de idade, em seus aspectos físico, psicológico, intelectual e social (art. 29). A mesma sendo oferecida em creches, ou entidades equivalentes, para crianças de até três anos de idade e em pré-escolas, para as crianças de quatro a cinco anos de idade (artgo 30). Foi com a reforma da educação em 2006 que o atendimento em pré-escola passou a ser para crianças de até cinco anos ${ }^{5}$ (artigo 29). Ainda que seja um direito adquirido pela criança, a educação infantil ainda não se tornou obrigatória em sua totalidade, sendo apenas obrigatória a partir de 4 anos (artigo 4ํㅜㅇ inciso I - Redação dada pela Lei no 12.796 (BRASIL, 2013), tendo caráter complementar à ação da família.

Após esse período de organização, estrutura e gestão da educação infantil no âmbito da educação básica, observamos um amplo desenvolvimento de documentos orientadores e dispositivos legais ${ }^{6}$ que estabeleceram

4 Redação dada pela Lei no 13.306 (BRASIL, 2016b).

5 A Educação Infantil passou a atender crianças de zero a cinco anos após a promulgação da lei do ensino fundamental de nove anos, Lei no 11.274 (BRASIL, 2006b), de 6 de fevereiro de 2006, e também pelo nova redação do Art. 29 da LDB, pela Lei no 12.796 (BRASIL, 2013).

6 No conjunto desses documentos e dispositivos legais produzidos no período de 1998 a 2014, se encontram: Referencial Curricular Nacional para a Educação Infantil (RCNEI) - volumes I, II e III (BRASIL, 1998); Diretrizes Curriculares Nacionais para a Educação Infantil (BRASIL, 1999); Resolução CEB no 1, de 7 de abril de 1999 (BRASIL, 1999); Plano Nacional de Educação, Lei no 10.172 (BRASIL, 2001); Parâmetros Nacionais de Qualidade 
discussões sobre o currículo, a prática e organização pedagógica, os aspectos relacionados a qualidade e a avaliação na educação infantil. Ficou nítido que a Educação Infantil, mesmo permeada de contradições, caminhava para uma efetiva organização, na busca por uma expansão com qualidade a todos os bebês e crianças.

A partir dos documentos e dispositivos legais propostos no período de 1998 a 2014, após o processo de inclusão da Educação Infantil como primeira etapa da Educação Básica, verificamos que houve concordância e necessidade em considerar a educação infantil uma etapa educativa para o desenvolvimento integral da criança, oferecendo condições de a criança se constituir cidadão de direito. Bogatschov e Moreira (2009, p. 10) afirmam que:

[...] para que isso se concretize é necessário primeiramente superar a relação dicotômica entre o cuidar e o educar. A questão que se coloca então é compreender os aspectos que envolvem essa mudança no discurso oficial sobre o atendimento à criança pequena, ou seja, quais as razões motivaram o Estado em buscar superar a dicotomia educar-cuidar no atendimento à infância no Brasil. Para compreender tal movimento é preciso, porém considerar o contexto que determinou tais transformações, ou seja, da totalidade histórica.

O binômio Educar e Cuidar, assumido pelo Referencial Curricular Nacional para a Educação Infantil (RCNEI), Diretrizes Curriculares para a Educação Infantil (1999 e 2009a), envolve a compreensão e a prática pedagógica em

para a Educação Infantil (PNQEI) - volume I e II (BRASIL, 2006c); Emenda Constitucional no 53 (BRASIL, 2006a); Parâmetros Básicos de Infraestrutura para Instituições de Educação Infantil (BRASIL, 2006d); Lei oㅡ 11.494 - FUNDEB (BRASIL, 2007); Emenda Constitucional no 59 (BRASIL, 2009b); Orientações sobre convênios entre secretarias municipais de educação e instituições comunitárias, confessionais ou filantrópicas sem fins lucrativos para a oferta de educação infantil (BRASIL, 2009c); Critérios para um Atendimento em Creches que Respeite os Direitos Fundamentais das Crianças (BRASIL, 2009d); Indicadores da Qualidade na Educação Infantil (BRASIL, 2009e); Diretrizes Curriculares Nacionais para a Educação Infantil (BRASIL, 2009a); O Monitoramento do Uso dos Indicadores da Qualidade na Educação Infantil (BRASIL, 2011); Plano Nacional de Educação, Lei no 13.005 (BRASIL, 2014). como ajudar o outro a se desenvolver, portanto significa valorizar e proporcionar à criança o desenvolvimento de suas capacidades, envolve a dimensão afetiva e os cuidados com os aspectos biológicos do corpo. Verifica-se um avanço no que concerne ao conceito de cuidado, que deve se expandir para além dos aspectos biológicos (BOGATSCHOV; MOREIRA, 2009).

Para o alcance dessa concepção na prática pedagógica nas redes de ensino, as Diretrizes Curriculares Nacionais para a Educação Infantil (BRASIL, 2009a, p. 17) estabeleceu que “[...] a proposta pedagógica das instituições de Educação Infantil deve garantir que elas cumpram plenamente sua função sociopolítica e pedagógica". Com isso alcançamos o patamar mais próximo para a construção de um Projeto de Educação Infantil Nacional, sob as diretrizes apontadas no Quadro 1.

Quadro 1 - Diretrizes a serem efetivadas nas propostas pedagógicas para a Educação Infantil

- Oferecendo condições e recursos para que as crianças usufruam seus direitos civis, humanos e sociais;

- Assumindo a responsabilidade de compartilhar e complementar a educação e cuidado das crianças com as famílias;

- Possibilitando tanto a convivência entre crianças, e entre adultos e crianças, quanto a ampliação de saberes e conhecimentos de diferentes naturezas;

- Promovendo a igualdade de oportunidades educacionais entre as crianças de diferentes classes sociais no que se refere ao acesso a bens culturais e às possibilidades de vivência da infância;

- Construindo novas formas de sociabilidade e de subjetividade comprometidas com a ludicidade, a democracia, a sustentabilidade do planeta e com o rompimento de relações de dominação etária, socioeconômica, étnico-racial, de gênero, regional, linguística e religiosa.

Fonte: Brasil (2009a, p. 2). 
Um dos avanços efetuados na política educacional para a educação infantil nas primeiras décadas do século XXI é a concepção de que a criança deve ser considerada:

[...] centro do planejamento curricular, é sujeito histórico e de direitos que, nas interações, relações e práticas cotidianas que vivencia, constrói sua identidade pessoal e coletiva, brinca, imagina, fantasia, deseja, aprende, observa, experimenta, narra, questiona e constrói sentidos sobre a natureza e a sociedade, produzindo cultura. (BRASIL, 2009a, p. 1).

Essa mudança de concepção e a efetivação do direito da criança à educação infantil, mesmo com todo o aparato legal e orientador implementado, permanece como um desafio a ser concretizado ainda no século XXI, pois no período de 1990 a 2001 a educação infantil foi permeada também com a concepção de insumo para a formação do capital humano, arrolada como uma etapa para a expansão do "cuidado" dos filhos da classe em situação de risco rumo a uma crença no "desenvolvimento econômico sustentável”. Essa concepção tem sua nascente nas orientações políticas traçadas na esfera do poder internacional e se tornaram o lema sob viés predominante do mercado, sendo implementadas políticas marcadas por conceitos ou slogans, como competências, habilidades, saberes necessários, educação ao longo da vida, Educação para Todos (EPT), ${ }^{7}$ Educação para Cidadania Global (ECG), ${ }^{8}$ Educação para o Desenvolvimento Sustentável (ODS). ${ }^{9}$

7 Lema definido na Conferência Mundial de Jontiem em 1990 e que definiu a agenda política para a educação dos países mais populosos e com pobreza extrema (ORGANIZAÇÃO DAS NAÇÕES UNIDAS PARA A EDUCAÇÃO, CIÊNCIA E A CULTURA, 1990).

8 De acordo com Bittencourt (2017, p. 561), “os princípios norteadores da ECG estão explicados em diversas publicações da UNESCO a partir de 2012, entre as quais destacamos dois, o documento denominado Repenser l'Éducation: vers un bien commun mondial, de 2015 e o documento traduzido para o português e publicado em 2016, Educação para Cidadania Global" (ORGANIZAÇÃO DAS NAÇÕES UNIDAS PARA A EDUCAÇÃO, A CIÊNCIA E A CULTURA, 2016).

9 Lema proposto para a Agenda da Educação 2030 aos países da América Latina e o Caribe a partir do Fórum Mundial de Educação (ORGANIZAÇÃO DAS NAÇÕES UNIDAS PARA A EDUCAÇÃO, A CIÊNCIA E A CULTURA, 2016).
Nos documentos oficiais do MEC assumiuse uma centralidade das propostas e ações, na qual a educação infantil foi considerada uma fase emergencial para a formação do trabalhador necessário para o mercado globalizado. Essa focalização priorizou a Educação Básica em detrimento das outras etapas da educação. Contudo, a priorização de investimentos no Ensino Fundamental (sete a catorze anos) foi sentida nas etapas da Educação Infantil e do Ensino Médio. Contradições entre as recomendações e os documentos legais marcaram um contexto educacional baseado em profundas reorganizações e reformas, por vezes descontínuas.

0 período foi marcado pelo princípio da educação para todos e gratuita, todavia, para a concretização das ações, vê-se que os benefícios destinados à primeira infância priorizaram as famílias de baixa renda. A perspectiva do direito expresso nas legislações educacionais e no macrossistema econômico apresenta-se de fato como uma perspectiva de necessidade e de continuísmos (MOREIRA; LARA, 2012).

É possível afirmar que, nas últimas três décadas, a ênfase no atendimento e cuidado à primeira infância passou a ser um dos eixos de atenção das políticas educacionais, juntamente com o emblemático discurso da qualidade da educação, da expansão, avaliação, crescimento e melhoria das creches e pré-escolas, medidas que priorizavam os mais desfavorecidos. Tal ênfase foi alcançada pelo engajamento expressivo das lutas sociais em defesa da democracia, da escola e da educação "como bem mais significativo da sociedade capaz de conduzir a emancipação dos sujeitos sociais" (CURY; REIS; ZANARDI, 2018, p. 7).

\section{Estado, o neoliberalismo e a Educação Infantil (2015- 2017)}

As políticas para a Educação Infantil efetivadas ao longo da trajetória histórica apresentada tiveram como movimento decisório para 
o seu delineamento as determinações a partir das relações que se definem no bojo da base produtiva da sociedade brasileira, nas quais se assentam e se engendram as necessidades das mais diversas ordens, dentre elas a educação. Nesse item temos como desafio explicitar de forma substancial as mudanças em relação ao Estado e ao neoliberalismo no atual contexto, mais precisamente nos três anos propostos para a análise.

Algumas considerações teórico-metodológicas são fundamentais para a interpretação acerca da influência do Estado e do neoliberalismo nas políticas para a educação infantil. Dentre elas destacamos as categorias Homem, ${ }^{10}$ Educação, Sociedade e Política. Os Homens, sendo condicionados pelo desenvolvimento das forças produtivas, estabelecem entre si relações sociais e políticas, que também são determinadas historicamente, tais como: a produção das ideias e da linguagem e as representações da consciência que estão ligadas às atividades do trabalho e das relações produzidas no e pelo mundo do trabalho (MARX; ENGELS, 1986). Nesse sentido, a Educação e suas reformas pensadas em tempos distintos, são produtos dos próprios pensamentos dos homens em Sociedade. Por Educação cabe aqui considerá-la como o processo de produção e assimilação do conhecimento produzido pelos homens em determinados contextos históricos e culturais, materializada como uma instituição social em unidades escolares, Universidades, espaços de processos escolares formais e não formais (MOREIRA, 2018). Para organizar a sociedade de mercado em que vivemos, um conjunto de relações é necessário para constituir a ordem produtiva: "[...] uma imensa e complexa superestrutura representada pelas formas jurídicas, políticas, religiosas, artísticas, filosóficas, em resumo pelas formas ideológicas" (SAVIANI, 2017, p. 222).

O conceito de Política se assenta como sinônimo de disputa de poder. As políticas não são apenas as ações que emanam do Estado;

10 Utilizamos o nome "Homem" como ser genérico. devem ser entendidas também como uma construção processual, um processo político que envolve negociações na arena de luta das classes antagônicas, exigindo contestação e disputa entre grupos com interesses antagônicos e diversos. "Política deve ser entendida como processo mais do que produto" (MOREIRA, 2015 , p. 28). No campo de conhecimento das Políticas Educacionais, a política refere-se ao estudo voltado para a compreensão de “[...] uma atividade ou conjunto de atividades, que de alguma forma ou de outra são imputadas ao Estado moderno capitalista ou dele emanam" (SHIROMA; MORAES; EVANGELISTA, 2002, p. 7). Contudo, a Política é o processo em que o Estado exerce o seu poder e controle no campo da ordenação, planejamento, legislação, todavia, havendo consentimento ou não (MOREIRA, 2015). Como também confirma Souza (2016, p. 76, grifo nosso):

[...] a política se traduz dominantemente na luta por poder, e a tensão em conquista-lo, mantê-lo e ampliá-lo compõe o contexto dos conflitos que ganham espaço na relação entre as demandas sociais por educação e o posicionamento do Estado diante destas demandas, seja atendendo-as ou não. Esta leitura sobre a política e suas decorrências na consagração e efetivação do direito à educação, compõe o campo de investigação das políticas educacionais.

Parte-se do desígnio das políticas educacionais para a Educação Infantil atualmente em reforma no Brasil se constituem em representações históricas, com significações que expressam aspectos ideológicos produzidas no contexto de mundialização da economia, na fase de vigência da acumulação financeirizada, flexível e do neoliberalismo. Desenhada por esse contexto, a educação infantil e suas reformas desde a mais tenra idade das crianças:

[...] trazem embutidas em sua concepção: uma escola (e uma 'educação') flexibilizada para atender as exigências e os imperativos empresariais; uma formação volátil, superficial e adestrada para suprir as necessidades do mercado de trabalho 'polivalente', 'multifuncional' e flexível. (ANTUNES, 2017, p. 12). 
Entende-se que as recomendações políticas para a educação infantil, contidas nos documentos produzidos, nas articulações e atuações estabelecidas com as organizações e organismos internacionais, redes sociais e privadas, têm-se concretizado e, também, são mediatizadas por forças e resistências intranacionais, podendo estar ou não expressas em leis, programas e ações do Estado, desenvolvidos ou não no âmbito educacional brasileiro. Nesse sentido, grupos privados e organismos internacionais detêm interesses na condução da política educacional hoje, mas são também permeados por enfrentamentos e resistências.

Considera-se que o Estado é produto da sociedade no estágio em que se encontra o capitalismo e possui o desígnio de colocar a sociedade em "harmonia" com o contexto da ordem e dos limites do capital. A proposta do Governo brasileiro no período em análise apresenta em seu Plano Governamental (FUNDAÇÃO ULYSSES GUIMARÃES, 2015) que o Estado deve ser funcional, e ações para minimizar ainda mais o seu papel na área social têm sido implementadas junto à iniciativa privada:

As discussões sobre o tamanho e o escopo do Estado quase sempre se movem no vazio, porque a questão central é que o Estado deve ser funcional, qualquer que seja o seu tamanho. Para ser funcional ele deve distribuir os incentivos corretos para a iniciativa privada $e$ administrar de modo racional e equilibrado os conflitos distributivos que proliferam no interior de qualquer sociedade (FUNDAÇÃO ULYSSES GUIMARÃES, 2015, p. 4, grifo nosso).

Diante de um contexto de ajustes fiscais e da reforma trabalhista, delineia-se uma diminuição do tamanho do Estado na área social, diminuição de investimentos e acirramento de formas exauridas de se gestar a educação infantil, aumentando a parceria com o setor privado, com as organizações sociais, contratações de profissionais da educação sem formação pedagógica, contratos temporários de trabalho e formas de trabalho intermitente.

No que concerne ao conceito de reforma educativa na Educação infantil, consideramos dois aspectos. 0 primeiro se refere à existência, desde a década de 1990, de uma padronização nas reformas educativas da América Latina, com ênfase nas categorias políticas de descentralização (SOUZA, 2003), de focalização e de mercantilização da educação pública. Outro aspecto a considerar é que as mudanças políticas e econômicas geraram o que entendemos como (anti)reformas atuais na educação pública brasileira. Moreira e Lara (2012), ao investigarem as políticas para a Educação Infantil no período de 1990 a 2001, detectaram que os elementos recorrentes constitutivos dos discursos políticos estiveram assentados nas categorias políticas da Qualidade, Descentralização e Focalização:

A ênfase no atendimento e cuidado à primeira infância passou a ser um dos eixos de atenção das políticas educacionais na década de 1990, juntamente com o emblemático discurso da qualidade da educação, da expansão, crescimento e melhoria das creches e pré-escolas, medidas que priorizavam os mais desfavorecidos. As creches e pré-escolas, até então caracterizadas como instituições assistenciais, a partir desse período foram inseridas no âmbito da educação, o que demandou diversas mudanças de caráter administrativo, pedagógico e político, com vista a estruturar a primeira etapa da Educação Básica. Novas regulamentações e definições deram os rumos para a nova configuração que se estabelecia nas instituições infantis. (MOREIRA; LARA, 2012, p. 226).

Após esse período, em meados da última década, no âmbito das políticas para a Educação Infantil ficou nítido o alinhamento com a política do desenvolvimento sustentável para a amenização da pobreza, paz mundial, controle do meio ambiente, presente atualmente na Agenda 2030 da Organização das Nações Unidas (ONU), com suas 17 metas e 169 estratégias (AÇÃO EDUCATIVA, 2017), foco da análise que apresentaremos no próximo item.

No atual contexto, especificamente a partir de 2013, é perceptível no Brasil que as mudanças estão a aniquilar as conquistas democráticas construídas desde o período de redemocratização do país. A efetivação dos in- 
teresses privatistas está intrinsecamente ligada aos interesses do mercado financeiro do capitalismo nacional e internacional, em novas ondas de expansão do pensamento conservador. Os Estados Democráticos, segundo Levitsky e Ziblatt (2018, p. 194) estão "recuando em todo mundo", caracterizando o que Dimond (2015) estabeleceu como "período de recessão democrática", o que acena para um cenário onde as políticas estão marcadas “[...] por polarizações, por um distanciamento maior das convenções políticas não escritas e por crescentes guerras institucionais - em outras palavras, uma democracia sem grades de proteção" (LEVITSKY; ZIBLATT, 2018, p. 198).

A ideia de reformar está intimamente relacionada à intenção de desenvolvimento e progresso. Salienta Souza (2003) que as reformas mais atuais possuem suas bases em postulados do individualismo liberal, o que acarreta em ações problemáticas:

[...] muitas vezes, o conjunto de problemas a ser solucionado pelas reformas educacionais é desconsiderado por elas, na medida em que essas têm muito pouca relação (para não dizer nenhuma!) com a cultura e o cotidiano da escola e estão muito mais voltadas a legitimar as formas de organização das sociedades industriais contemporâneas. (SOUZA, 2003, p. 25).

Diante dessa consideração, entende-se o panorama atual como (anti)reformas, pois não dão continuidade ao encaminhamento das políticas anteriores, retrocedendo o avanço da democracia e da justiça social. Souza (2003) nos proporciona elementos para inquirir se as reformas educacionais estão voltadas para as mudanças radicais. Na visão desse autor, podese afirmar que aparentemente sim, todavia isto nem sempre ocorre:

[...] muitas vezes o objetivo da reforma é somente transformar ou romper com uma dada prática social, mas ao desconsiderar as formas pelas quais as escolas reagem ao recebimento das suas determinações, as reformas falham, mesmo que parcialmente. E ainda, e principalmente, em alguns casos as reformas buscam mudar tudo para deixar tudo do mesmo jeito que estava... (SOUZA, 2003, p. 27, grifo nosso).
Uma política pública é elaborada e colocada em ação por meio de uma reforma, possui intencionalidades, objetivos, público-alvo, mecanismos de financiamento e implementação. Ao tratar de uma política pública, sua elaboração deve essencialmente primar pelo debate público, sobretudo quando os objetivos deverão focar a sociedade e não os agentes privados. Contudo, defendemos que, no processo atual, o que está a ocorrer é um conjunto de medidas intermitentes que se configuram em (anti)reforma, pois destituiu o debate público de forma arbitrária, despreza a opinião de estudantes, de trabalhadores da educação e de especialistas da área.

\section{Educação 2030 e a ODS4 para a Educação Infantil no Brasil}

As organizações internacionais UNESCO, o UNICEF, o Banco Mundial, o UNFPA, o PNUD, a ONU Mulheres e o ACNUR organizaram o Fórum Mundial de Educação 2015, em Incheon, na Coreia do Sul, entre 19 e 22 de maio de 2015, para discutirem a agenda da educação no mundo nos próximos 15 anos. Compareceram ao evento mais de 1.600 participantes de 160 países, incluindo mais de 120 ministros, chefes e membros de delegações, líderes de agências e funcionários de organizações multilaterais e bilaterais, além de representantes da sociedade civil, da profissão docente, do movimento jovem e do setor privado. Na ocasião aprovaram e decidiram adotar a Declaração de Incheon e suas premissas para a Agenda de Educação 2030, que estabelece uma nova visão para a educação nos próximos 15 anos.

No documento ratificado no Fórum Mundial de Educação em 2015, intitulado Educação 2030: Declaração de Incheon e Marco de Ação para a implementação do Objetivo de Desenvolvimento Sustentável 4, encontramos registrada a proposta da "nova visão" para a educação. Ressaltam que "[...] essa nova visão é inteiramente captada pelo ODS 4 - Assegurar a educação inclusiva e equitativa de qualidade, 
e promover oportunidades de aprendizagem ao longo da vida para todos" e suas metas correspondentes (ORGANIZAÇÃO DAS NAÇÕES UNIDAS PARA A EDUCAÇÃO, A CIÊNCIA E A CULTURA, 2016, p. 7). A Declaração de Incheon, que constitui o compromisso da comunidade de educação em relação à Agenda Educação 2030 mundial, confiou à Unesco a função de liderar, coordenar e ser o ponto focal para a educação no âmbito da coordenação principal dos ODS.

No ODS 04 encontramos a Meta 4.2, que é específica para a agenda da primeira infância. Aliada ao reconhecimento de que a educação é elemento-chave para atingir o pleno emprego e a erradicação da pobreza, a meta expressa que: "Até 2030, garantir que todas as meninas e meninos tenham acesso ao desenvolvimento de qualidade na primeira infância, cuidados e educação pré-primária, de modo que estejam preparados para a educação primária" (ORGANIZAÇÃO DAS NAÇÕES UNIDAS PARA A EDUCAÇÃO, A CIÊNCIA E A CULTURA, 2016, p. 20, grifo nosso)

Nessa meta identificamos dois aspectos que historicamente estiveram presentes na Educação Infantil e que os movimentos sociais e pesquisadores da área lutam arduamente para superar. Contudo, a orientação presente na agenda E2030 é de um retrocesso banal quando, primeiramente, apresenta uma concepção de educação infantil como etapa preparatória para fases posteriores de escolarização; no caso brasileiro, como preparo para o ensino fundamental. Essa concepção a ser superada esteve presente a partir da década de 1980, conforme já mencionado nesse texto, e vai contra os próprios princípios pedagógicos da educação infantil instituídos nas DCNEI (BRASIL, 2009a).

Um segundo aspecto refere-se à educação infantil como etapa para escolarização de crianças. Incide aqui a concepção de prática pedagógica centrada no excesso de atividades de escolarização que se caracteriza nos encaminhamentos precoces para a alfabetização. São as recorrentes propostas que se pautam nas
[...] perspectivas lineares e escolarizantes de trabalho com as crianças, com programas pautados em listas de atividades, que geralmente concebem a ideia de que, para aprender, as crianças devem primeiramente sentir, depois pensar e, finalmente, comunicar, sempre do mais fácil para o mais difícil e do individual para o coletivo. (CARVALHO; FOCCHI, 2017, p. 16).

A Agenda E2030 apresenta a sigla ECCE para a expressão Educação e o Cuidado na Primeira Infância, ${ }^{11}$ que tece orientações pautadas em princípios a serem alcançados ao longo da vida. A expressão "ao longo da vida" tem sido recorrente nos documentos internacionais, constituindo-se no eixo norteador das políticas educacionais, nomeadamente a partir da década de 1990. Nos documentos internacionais, quando se referem a educação ao longo da vida, o sentido está no ajustamento e na adaptação do indivíduo. Sobre a análise do que concerne o conceito, Rodrigues (2008, p. 162) pondera que:

[...] a noção de educação ao longo da vida vai além das mudanças prescritas aos sistemas educacionais em seu conjunto; visa, acima de tudo, conformar uma relação dos sujeitos na história, almejando no horizonte deste projeto educacional um sujeito despolitizado, atomizado, sem qualquer capacidade organizativa e sem condições de pensar-se como sujeito coletivo, apenas 'homens-massa', na célebre expressão gramsciana. Estes se constituem, a nosso ver, os limites e possibilidades pensados para o percurso da vida do indivíduo sob a égide de tal projeto de educação.

A educação ao longo da vida, desde a inserção da criança na educação infantil, se expressa no binômio educar e cuidar, a partir de uma concepção da educação infantil como etapa preparatória, compensatória e assistencialista, focada no bem-estar, na nutrição e no cuidado:

A ECCE constrói os fundamentos para o aprendizado ao longo da vida, assim como apoia o bem-estar das crianças e o preparo progressivo para o ingresso na escola primária - transição importante e muitas vezes acompanhada por expectativas cada vez maiores do que as crianças deveriam saber ou conseguir fazer. 'A

11 Early Childhood Care and Education (ECCE). 
prontidão para a escola primária' refere-se à conquista de marcos em diversos domínios, inclusive status de saúde e nutrição adequadas e desenvolvimento linguístico, cognitivo, social e emocional apropriado para a idade. Para que isso seja alcançado, é importante que todas as crianças tenham acesso a um desenvolvimento educacional na primeira infância holístico e de qualidade, bem como a cuidados e educação para todas as idades. (ORGANIZAÇÃO DAS NAÇÕES UNIDAS PARA A EDUCAÇÃO, A CIÊNCIA E A CULTURA, 2015, p. 39, grifo nosso).

0 enunciado expressa que é importante que "[...] todas as crianças tenham acesso a um desenvolvimento educacional na primeira infância" (ORGANIZAÇÃO DAS NAÇÕES UNIDAS PARA A EDUCAÇÃO, A CIÊNCIA E A CULTURA, 2015 , p. 39, grifo nosso), todavia, a própria recomendação se contradiz ao defender que a oferta da educação à primeira infância deve ser incentivada para "[...] pelo menos um ano de educação pré-primária, gratuita, compulsória e de qualidade [...]" (ORGANIZAÇÃO DAS NAÇÕES UNIDAS PARA A EDUCAÇÃO, A CIÊNCIA E A CULTURA, 2015, p. 39, grifo nosso).

Outro aspecto preocupante é o conteúdo dos enunciados que focalizam as ações na educação infantil efetuadas em grupos marginalizados. Em pleno século XXI permanece a ideia no âmbito internacional de que a escolarização de crianças na educação infantil deve promover o desenvolvimento da nação. Tal qual analisamos no início do século XX, ainda está presente a raiz histórica da infância como problema social e conserva-se a concepção da infância como um valor econômico para o desenvolvimento da nação, como campo de formação para o capital humano:

A ECCE constrói as competências e as habilidades que capacitam as pessoas a aprender ao longo da vida e a ganhar sua subsistência. Investimentos em crianças pequenas, principalmente as de grupos marginalizados, produzem os maiores impactos a longo prazo em termos de resultados educacionais e de desenvolvimento. (ORGANIZAÇÃO DAS NAÇÕES UNIDAS PARA A EDUCAÇÃO, A CIÊNCIA E A CULTURA, 2015, p. 38 , grifo nosso).

Fica evidente a concepção de uma intencionalidade laboral atribuída à educação dos bebês e crianças na educação infantil por meio de uma relação na escala estritamente econômica com o trabalho e com a ordem e civilidade da nação, já se anunciando para a potencialização da qualificação profissional e o desenvolvimento produtivo via resultados educacionais. O trabalho, nesta concepção assentada em competências e habilidades no currículo para a educação infantil, traduz exatamente o modelo de uma organização produtiva flexível que visa modelar a criança ainda pequena de acordo com as necessidades do desenvolvimento capitalista (PUZIOL; MOREIRA, 2009).

A partir das recomendações, o Documento da Agenda E2030 expõe algumas estratégias para alcançar a meta 4.2 do ODS4. Com as análises dos enunciados identificamos as categorias políticas, apresentadas no Quadro 2.

Quadro 2 - Categorias políticas para a educação infantil presentes nos enunciados da Educação 2030: Declaração de Incheon e Marco de Ação para a implementação do Objetivo de Desenvolvimento Sustentável 4.

\begin{tabular}{|l|l|c|}
\hline \multicolumn{1}{|c|}{ Categoria } & \multicolumn{1}{c|}{ Enunciado } & Página \\
\hline $\begin{array}{l}\text { Ausência de } \\
\text { Universalização }\end{array}$ & $\begin{array}{l}\text { Instituir políticas e leis integradas e inclusivas que garantam a oferta } \\
\text { de pelo menos um ano de educação pré-primária compulsória } \\
\text { e de qualidade, com especial atenção em alcançar as crianças mais } \\
\text { pobres e desfavorecidas por meio de serviços de ECCE. Isso } \\
\text { Qualidade }\end{array}$ & 39 \\
\cline { 1 - 3 } $\begin{array}{l}\text { Focalização na avaliações de políticas e programas de ECCE para melhorar } \\
\text { pobreza }\end{array}$ & $\begin{array}{l}\text { sua qualidade. } \\
\text { Avaliação }\end{array}$ & \\
\hline
\end{tabular}




\begin{tabular}{|l|l|c|}
\hline $\begin{array}{l}\text { Multissetorialidade } \\
\text { e Intersetorialidade }\end{array}$ & $\begin{array}{l}\text { Instituir políticas e estratégias multissetoriais de ECCE, apoiadas } \\
\text { pela coordenação entre ministérios responsáveis por nutrição, saú- } \\
\text { de, proteção social e infantil, água/saneamento, justiça e educação, } \\
\text { além de garantir recursos adequados para sua implementação. }\end{array}$ & 39 \\
\hline $\begin{array}{l}\text { Profissionalização } \\
\text { do pessoal }\end{array}$ & $\begin{array}{l}\text { Elaborar políticas, estratégias e planos de ação claros para a pro- } \\
\text { fissionalização do pessoal de ECCE, para aprimorar e monitorar } \\
\text { seu desenvolvimento profissional, seu status e suas condições de } \\
\text { trabalho. }\end{array}$ & 39 \\
\hline $\begin{array}{l}\text { Ausência da } \\
\text { denominação de } \\
\text { professor }\end{array}$ & $\begin{array}{l}\text { Conceber e implementar programas, serviços e infraestrutura de } \\
\text { qualidade, para a primeira infância, que sejam também inclusivos, } \\
\text { acessíveis e integrados e abranjam necessidades de saúde, nutrição, } \\
\text { proteção e educação, principalmente para crianças com deficiên- } \\
\text { cias, e o apoio a famílias como os responsáveis pelos primeiros cui- } \\
\text { dados das crianças. }\end{array}$ & 39 e 40 \\
\hline Qualidade & Inclusão &
\end{tabular}

Fonte: Elaborado pela autora baseando-se em Organização das Nações Unidas para a Educação, a Ciência e a Cultura (2015, p. 39-40, grifo nosso).

Nos dias 24 e 25 de janeiro de 2017, a Unesco promoveu a Reunião da Cúpula dos ministros de educação latino-americanos e caribenhos, em Buenos Aires. O ex-Ministro da Educação Mendonça Filho ${ }^{12}$ (DEM) esteve presente na ocasião e apresentou um panorama das políticas educacionais desenvolvidas no Brasil (MINISTÉRIO DA EDUCAÇÃO, 2017). A Organização ressaltou os avanços e problemas das políticas educacionais desenvolvidas na última década e orientou para as formas de atingir os objetivos da Agenda 2030 para o Desenvolvimento Sustentável.

A Reunião teve como tema E2030: Educação e habilidades do século 21, e foi a primeira reunião de cúpula regional para tratar do objetivo número 4 da Agenda 2030. Durante a reunião, discutiu-se sobre os objetivos globais e sobre o relatório Educação 2030 - Diretrizes para a Ação, aprovado pela comunidade internacional em novembro de 2015 no Fórum Mundial da Educação, já mencionado anteriormente em nossas análises. Destacou-se que o documento oferece, aos governos e parceiros, diretrizes para transformar compromissos em ações. Ao final das discussões da reunião, lançou-se a Declaração de Buenos Aires, a qual a Unesco afirma que representa a visão regional para a educação até 2030 e norteará as estratégias e programas no âmbito nacional dos países signatários (ORGANIZAÇÃO DAS NAÇÕES UNIDAS, 2017).

No âmbito da Educação Infantil, identificamos a categorização política na Declaração de Buenos Aires (ORGANIZAÇÃO DAS NAÇÕES UNIDAS, 2017), apresentada no Quadro 3.

Quadro 3 - Categorias políticas para a educação infantil presentes nos enunciados da Declaração de Buenos Aires para a educação infantil.

\begin{tabular}{|c|l|c|}
\hline Categoria & \multicolumn{1}{|c|}{ Enunciado } & Página \\
\hline Etapa Preparatória & $\begin{array}{l}\text { De aquí a 2030, velar por que todas las niñas y todos los niños ten- } \\
\text { gan acceso a servicios de atención y desarrollo en la primera in- } \\
\text { fancia y a una enseñanza preescolar de calidad, a fin de que estén } \\
\text { preparados para la enseñanza primaria. }\end{array}$ & 6 \\
\hline
\end{tabular}

12 Exerceu o cargo de Ministro da Educação no período de 12 de maio de 2016 a 6 de abril de 2018. 


\begin{tabular}{|l|l|c|}
\hline $\begin{array}{l}\text { Focalização na } \\
\text { pobreza }\end{array}$ & $\begin{array}{l}\text { Reafirmamos el compromiso de continuar avanzando en la expan- } \\
\text { sión de los programas de atención y educación de la primera infân- } \\
\text { cia, priorizando aquellos grupos marginados y/o excluidos, a } \\
\text { partir de una oferta de calidad que promueva el desarrollo inte- } \\
\text { gral de niños y niñas, con la participación activa de las familias } \\
\text { y comunidades, y que se encuentre articulada interinstitucional e } \\
\text { intersectorialmente, asegurando así el éxito escolar en los ciclos } \\
\text { sucessivos. }\end{array}$ & 8 \\
\hline Parcerias & Intersetorialidade & \\
\hline
\end{tabular}

Fonte: Elaborado pela autora baseando-se em Organização das Nações Unidas (2017, p. 6-8, grifo nosso).

\section{Conclusão}

Nas análises mediadas retomamos uma breve contextualização histórica acerca de praticamente 200 anos de história da educação infantil no Brasil. Ao discorrer sobre o surgimento das primeiras instituições para as crianças pequenas e ao abordarmos uma explanação das políticas recomendadas no período atual (2015 a 2017), visualizamos que ainda defendemos o óbvio e lutamos pela universalização e pela qualidade, para que a educação infantil alcance a todos e a todas as crianças.

As recomendações internacionais da Unesco e agências parceiras presentes na Agenda E2030 aos países da América Latina e o Caribe nos mostram que as políticas para a educação infantil são orientadas para a focalização na pobreza, para um atendimento prioritário aos marginalizados e excluídos. Defendem que a educação infantil deve ser uma etapa preparatória para o ensino fundamental. Nesse sentido, foi possível identificar a seguinte categorização política nos documentos internacionais analisados: Ausência de Universalização, Qualidade, Focalização na Pobreza, Avaliação, Multissetorialidade e Intersetorialidade, Parcerias, Profissionalização do Pessoal e Ausência da Denominação da Função de Professor.

Essas recomendações de maneira alguma propiciarão a qualidade que se almeja, pois se percebe também uma política que descaracteriza o professor na educação infantil, uma vez que a Agenda E2030 se ausenta em apresentar a palavra "professor" na meta 4.2 do ODS4 e se refere de forma abrangente e genérica à "profissionalização de pessoal". Cabe aqui o entendimento da presença daquele velho dilema de retomada das políticas retrógradas que consideram que para educar e cuidar das crianças não há necessidade de ser um professor - o profissional com formação pedagógica -, mas qualquer pessoal que faz parte do quadro de funcionários, até mesmo sem a formação pedagógica específica.

As parcerias por meio de políticas multissetoriais e intersetorias são recomendações recorrentes. E também expressam a velha política e gestão que não trouxe profícuos resultados no contexto brasileiro. Desde a origem das instituições infantis no Brasil, cabia aos setores da assistência social, das entidades religiosas e da filantropia o atendimento nas instituições infantis. A expansão dessas instituições, o crescimento de creches e centros de educação infantil no país e a responsabilidade exclusiva do sistema de ensino municipal trouxeram avanços nos quesitos ampliação e organização pedagógica, mas sempre aliando aos mecanismos políticos de conveniamento, filantropia, parcerias com escolas comunitárias, confessionais e privadas. Nota-se, gradativamente, uma tendência crescente de terceirização do atendimento, que se agrava no contexto atual com a aprovação da Emenda Constitucional no 95 (BRASIL, 2016a), que instituiu o teto de gastos, congelando por 20 anos os investimentos no setor da educação e saúde. 
Outra forma de intersetorialidade são as retomadas de ações pautadas no assistencialismo. Um exemplo dessa ação é o atual Programa Criança Feliz, lançado no início do mandato de Michel Temer. As ações deste programa se assentam no desenvolvimento de políticas intersetorias sendo planejadas e acordadas por meio de diversas parcerias de responsabilidades divididas com os setores tanto público como privado, correspondendo ao que a própria diretriz de inter e multissetorialidade que a Unesco recomenda para o alcance do desenvolvimento sustentável e com o intuito de cumprir com a Meta 4.2. Braz e Moreira (2018) ressaltam que há uma atenção para outra questão, que é a presença de uma a visão holística como embasamento, mas que na prática acaba por vincular-se ao assistencialismo e à concepção de prontidão/preparação para a escolarização se caracterizando como retrógrado (ARELARO, 2018) e destoando da política nacional para a educação infantil.

Ao encerrar este texto, a convicção que se tem é que caminhamos para uma manutenção de propostas conservadoras e ultrapassadas para a Educação Infantil. Preocupa-nos o resultado da implementação da agenda E2030 e do ODS4 em sua meta 4.2, centrada nas categorizações anunciadas aqui, pois, diante do exposto, não se vislumbra a universalização da educação infantil para todos os bebês e crianças, instituída na meta 01 do atual PNE; não há uma política recomendada para a valorização do profissional professor nessa etapa educativa. 0 que nos leva a crer que não estamos a reformar a educação infantil, mas a (anti)reformar. Sigamos convencidos que a luta alargou.

\section{REFERÊNCIAS}

ABRAMOWICZ, Anete. Pesquisa e extensão em políticas públicas na Educação Infantil. In: REUNIÃO NACIONAL DA ANPeD, 25., 2002, Caxambú, MG. Anais... Caxambú, NG: ANPeD, 2002. GT 7, Educação Infantil. Disponível em: <http://www. prac.ufpb.br/anais/Icbeu_anais/anais/educacao/ politicaspublicas.pdf>. Acesso em: 17 set. 2018.
AÇÃO EDUCATIVA. A implementação dos objetivos de desenvolvimento sustentável no Brasil e os desafios das metas em educação. São Paulo, 2017.

ALVES, Giovanni. Neodesenvolvimentismo ou crônica de uma morte anunciada. In. LUCENA, Carlos; PREVITELI, Fabiane Santana; LUCENA, Lurdes (Org.). A crise da democracia brasileira. Uberlândia, MG: Navegando Publicações, 2017. p. 129-148.

ANTUNES, R. Da educação utilitária fordista à da multifuncionalidade liofilizada. In: REUNIÃO NACIONAL DA ANPeD, 38., 2017, São Luis. Anais... São Luis: UFMA, 2017. Gt 11, Política da Educação Superior. Disponível em: <http://38reuniao.anped. org.br/programacao/2?field_prog_gt_target_id_ entityreference_filter $=14>$. Acesso em: 14 jun. 2018.

ARELARO, Lisete Regina Gomes. Avaliação das políticas de educação infantil no Brasil: avanços e retrocessos. Revista Zero-a-seis, v. 19, n. 36, p. 206-222, jul./dez. 2018.

BITTENCOURT, Jane. A Base Nacional Comum Curricular: uma análise a partir do ciclo de políticas. In: CONGRESSO NACIONAL DE EDUCAÇÃO, 13., 2017, Curitiba. Anais... Curitiba: PUC/PR, 2017.

BOGATSCHOV, Darlene Novacov; MOREIRA, Jani Alves da Silva. Políticas educacionais para o atendimento à infância no Brasil: do assistencialismo à indissociabilidade entre cuidar-educar. 2009. Disponível em: <http://www.histedbr.fe.unicamp. br/acer_histedbr/seminario/seminario8/_.../ hWvZXIMc.doc>. Acesso em: 25 jan. 2018.

BRASIL. Constituição da República Federativa do Brasil. São Paulo: Imprensa Oficial do Estado, 1988. . Presidência da República. Casa Civil. Lei n.o 8.069, de 13 de julho de 1990. Dispõe sobre o Estatuto da Criança e do Adolescente e dá outras providências. Brasília, DF, 1990. Disponível em: <http://www.planalto.gov.br/ccivil_03/leis/ L8069.htm>. Acesso em: 17 mar. 2019.

. Ministério da Educação. Lei $\mathbf{n}^{\circ}$ 9.394, de 20 de dezembro de 1996. Estabelece as diretrizes e bases da educação nacional. Brasília, DF, 1996. Disponível em: <http://www.planalto.gov.br/ ccivil_03/LEIS/L9394.htm>. Acesso em: 17 set. 2018.

. Ministério da Educação. Referencial Curricular Nacional para a Educação Infantil. Brasília, DF, 1998. Vol. I, II e III. 
. Ministério da Educação. Resolução CEB no 01, de 07 de abril de 1999. Institui as Diretrizes Curriculares Nacionais para a Educação Infantil. Brasília, DF, 1999.

Ministério da Educação. Lei n 10.172, de 09 de janeiro de 2001. Aprova o Plano Nacional de Educação e dá outras providências. Brasília, DF, 2001. Disponível em: <http://www.planalto. gov.br/ccivil_03/LEIS/LEIS_2001/L10172.htm> Acesso em: 17 set. 2018.

Emenda Constitucional no 53 , de 19 de dezembro de 2006. Dá nova redação aos artigos 7ํ, 23, 30, 206, 208, 211 e 212 da Constituição Federal e ao artigo 60 do Ato das Disposições Constitucionais transitórias. Brasília, DF, 2006a. Disponível em: <http://www.planalto.gov.br/ ccivil_03/Constituicao/Emendas/Emc/emc53. htm>. Acesso em: 17 set. 2018.

Lei no 11.274, de 06 de fevereiro de 2006. Altera a redação dos arts. 29, 30, 32 e 87 da Lei no 9.394, de 20 de dezembro de 1996, que estabelece as diretrizes e bases da educação nacional, dispondo sobre a duração de 9 (nove) anos para o ensino fundamental, com matrícula obrigatória a partir dos 6 (seis) anos de idade. Brasília, DF, 2006b. Disponível em: <http://www.planalto.gov. br/ccivil_03/_Ato2004-2006/2006/Lei/L11274. htm>. Acesso em: 17 set. 2018.

Ministério da Educação. Secretaria de Educação Básica. Parâmetros nacionais de qualidade para a educação infantil. Brasília, DF, 2006c.

Ministério da Educação. Secretaria de Educação Básica. Parâmetros Básicos de Infra-estrutura para Instituições de Educação Infantil. Brasília, DF, 2006d.

- Presidência da República. Casa Civil. Lei n. ${ }^{\mathbf{o}}$ 11.494, de 20 de junho de 2007. Regulamenta o Fundo de Manutenção e Desenvolvimento da Educação Básica e de Valorização dos Profissionais da Educação - FUNDEB, de que trata o art. 60 do Ato das Disposições Constitucionais Transitórias; altera a Lei no 10.195, de 14 de fevereiro de 2001; revoga dispositivos das Leis nos 9.424, de 24 de dezembro de 1996, 10.880, de 9 de junho de 2004, e 10.845, de 5 de março de 2004; e dá outras providências. Brasília, DF, 2007. Disponível em: <http://www. planalto.gov.br/ccivil_03/_Ato2007-2010/2007/ Lei/L11494.htm>. Acesso em: 17 set. 2018.

. Ministério da Educação. Conselho Nacional de Educação. Câmara de Educação Básica. Resolução CNE/CEB no 5, de 17 de dezembro de 2009.
Fixa as Diretrizes Curriculares Nacionais para a Educação Infantil. Brasília, DF, 2009a. Disponível em: <www.seduc.ro.gov.br/portal/legislacao / RESCNE005_2009.pd>. Acesso em: 17 set. 2018.

Emenda Constitucional no 59, de 11 de dezembro de 2009. Acrescenta $\S 3^{\circ}$ ao art. 76 do Ato das Disposições Constitucionais Transitórias para reduzir, anualmente, a partir do exercício de 2009, o percentual da Desvinculação das Receitas da União incidente sobre os recursos destinados à manutenção e desenvolvimento do ensino de que trata o art. 212 da Constituição Federal, dá nova redação aos incisos I e VII do art. 208, de forma a prever a obrigatoriedade do ensino de quatro a dezessete anos e ampliar a abrangência dos programas suplementares para todas as etapas da educação básica, e dá nova redação ao $§ 4^{0}$ do art. 211 e ao $\S 3^{\circ}$ do art. 212 e ao caput do art. 214 , com a inserção neste dispositivo de inciso VI. Brasília, DF, 2009b. Disponível em: <http://www.planalto. gov.br/ccivil_03/Constituicao/Emendas/Emc/ emc59.htm>. Acesso em: 17 set. 2018.

Ministério da Educação. Orientações sobre convênios entre secretarias municipais de educação e instituições comunitárias, confessionais ou filantrópicas sem fins lucrativos para a oferta de educação infantil. Brasília, DF, 2009c.

Ministério da Educação. Critérios para um atendimento em creches que respeitem os direitos fundamentais das crianças. Brasília, DF, 2009d.

Ministério da Educação. Indicadores da Qualidade na Educação Infantil. Brasília, DF, 2009e.

Ministério da Educação. 0 Monitoramento do uso dos indicadores da qualidade na educação infantil. Brasília, DF, 2011.

Presidência da República. Casa Civil. Lei n.o 12.796, de 04 de abril de 2013. Altera a Lei no 9.394, de 20 de dezembro de 1996, que estabelece as diretrizes e bases da educação nacional, para dispor sobre a formação dos profissionais da educação e dar outras providências. Brasília, DF, 2013. Disponível em: <http://www.planalto.gov. br/ccivil_03/_Ato2011-2014/2013/Lei/L12796. htm>. Acesso em: 17 mar. 2019.

Ministério da Educação. Lei n 13.005, de 25 de junho de 2014. Aprova o Plano Nacional de Educação e dá outras providências. Brasília, DF, 2014. Disponível em: <http://www.planalto.gov. br/ccivil_03/_Ato2011-2014/2014/Lei/L13005. 
htm>. Acesso em: 17 set. 2018.

Emenda Constitucional n.o 95. Altera o Ato das Disposições Constitucionais Transitórias, para instituir o Novo Regime Fiscal, e dá outras providências. 2016a.

. Lei n.o 13.306, de 4 de julho de 2016. Altera a Lei no 8.069, de 13 de julho de 1990 - Estatuto da Criança e do Adolescente, a fim de fixar em cinco anos a idade máxima para o atendimento na educação infantil. Brasília, DF, 2016b. Disponível em: <http://www.planalto.gov.br/ccivil_03/_ Ato2015-2018/2016/Lei/L13306.htm>. Acesso em: 17 de set. 2018.

BRAZ, Nádia Maria Qualio; MOREIRA, Jani Alves da Silva. 0 Programa Criança Feliz e sua relação com o direito à educação infantil. 2018. Relatório de Pesquisa do Programa de Iniciação Científica, Maringá, PR, 2018.

CARVALHO, Rodrigo Saballa de; FOCCHI, Paulo Sergio. A pedagogia do cotidiano na (e da) educação infantil. Em Aberto, Brasília, DF, v. 30, n. 100, p. 15-19, set./dez. 2017.

CURY, C. R. J. Educação e contradição: elementos metodológicos para uma teoria crítica do fenômeno educativo. São Paulo: Cortez, 1986.

CURY, Carlos Jamil; REIS, Magali; ZANARDI, Teodoro Adriano Costa. Base Nacional Comum Curricular: dilemas e perspectivas. São Paulo: Cortez, 2018.

DÁVILLA, Jerry. Eugenia, educação e políticas públicas no Brasil: entrevista ao Blog de HCSManguinhos. 2015. Disponível em: <http://www. revistahcsm.coc.fiocruz.br/eugenia-educacao-epoliticas-publicas-no-brasil/>. Acesso em: 17 set. 2018.

DIMOND, Larry. Facing up to the democratic recession. Journal of Democracy, v. 26. n. 1, p. 141-155, jan. 2015.

FUNDAÇÃO ULYSSES GUIMARÃES. Uma ponte para o futuro. Brasília, DF, 2015.

GOHN, Maria da Glória. Lutas e movimentos pela educação no Brasil a partir de 1970. Eccos - Revista Científica, v. 2, n. 1, p. 23-38, jan./jun. 2009.

KRAMER, Sonia. A política do pré-escolar no Brasil: a arte do disfarce. 3. ed. Rio de Janeiro: Dois Pontos, 1987.

KUHLMANN JÚNIOR, Moysés. Infância e educação infantil: uma abordagem histórica. Porto Alegre: Mediação,1998.
Histórias da educação infantil brasileira. Revista Brasileira de Educação, São Paulo, n. 14, p. 5-18, maio/ago.2000.

LEVITSKY, Steven; ZIBLATT, Daniel. Como as democracias morrem. Rio de Janeiro: Zahar, 2018.

MARX, K.; ENGELS, F. A ideologia alemã. Tradução José Carlos Bruni e Marco Aurélio Nogueira. 5. ed. São Paulo: Hucitec, 1986.

MINISTÉRIO DA EDUCAÇÃO E CULTURA - MEC. Encontro realizado pela Unesco na Argentina promove debate voltado à educação inclusiva. 2017. Disponível em: <http://portal.mec.gov. br/ultimas-noticias/222-537011943/44411encontro-realizado-pela-unesco-na-argentinapromove-debate-voltado-a-educacao-inclusiva>. Acesso em: 18 set. 2018.

MOREIRA, J. A. da S. Políticas de financiamento e gestão da educação básica (1990-2010): os casos Brasil e Portugal. Maringá, PR: Eduem, 2015.

Reformas educacionais e políticas curriculares para a educação básica: prenúncios e evidências para uma resistência ativa. Revista Germinal, v. 10, n. 2, p. 199-213, 2018. Disponível em: <https:// portalseer.ufba.br/index.php/revistagerminal/ article/view/27355/16674>. Acesso em: 24 set. 2018.

MOREIRA, Jani Alves da Silva; LARA, Angela Mara de Barros. Políticas públicas para a educação infantil no Brasil (1990-2001). Maringá: Eduem, 2012. MOVIMENTO INTERFÓRUNS DE EDUCAÇÃO INFANTIL DO BRASIL - MIEIB. Carta compromisso do MIEIB. Manaus, 2018. Disponível em: <http:// www.mieib.org.br/wp-content/uploads/2018/08/ XXXIV-Encontro-Nacional-Carta-VF-29.08.pdf>. Acesso em: 17 mar. 2019.

OLIVEIRA, Zilma Ramos de. A creche no Brasil: mapeamento de uma trajetória. Revista da Faculdade de Educação da USP, São Paulo, v. 14, n. 1, p. 43-52, jan./jun. 1988. Disponível em: <http:// www.revistas.usp.br/rfe/article/view/33402>. Acesso em: 17 mar. 2019.

ORGANIZAÇÃO DAS NAÇÕES UNIDAS - ONU. ODS4. Educação de qualidade. 2018. Disponível em: <https://nacoesunidas.org/pos2015/ods4/>. Acesso em: 17 set. 2018.

UNESCO promove cúpula em Buenos Aires sobre futuro da educação na América Latina e Caribe. 2017a. Disponível em: <https:// nacoesunidas.org/unesco-promove-cupula-em- 
buenos-aires-sobre-futuro-da-educacao-naamerica-latina-e-caribe/>. Acesso em: 15 ago. 2018.

Conheça os novos 17 objetivos de Desenvolvimento Sustentável da ONU. 2017b. Disponível em: <https: //nacoesunidas.org/conheca-os-novos17-objetivos-de-desenvolvimento-sustentavel-daonu/>. Acesso em: 17 mar. 2019.

ORGANIZAÇÃO DAS NAÇÕES UNIDAS PARA A EDUCAÇÃO, A CIÊNCIA E A CULTURA - UNESCO. Declaração Mundial sobre Educação para Todos: satisfação das necessidades básicas de aprendizagem. Jomtien, 1990.

Declaração de Incheon. Incheon, 2015.

Declaración de Buenos Aires: Reunión Regional de Ministros de Educación de América Latina y el Caribe. 2017.

Educação 2030: Declaração de Incheon e Marco de Ação; rumo a uma educação de qualidade inclusiva e equitativa e à educação ao longo da vida para todos. Brasília, DF, 2016. Disponível em: <http://www.unesco.org/new/pt/brasilia/aboutthis-office/single-view/news/education_2030_ incheon_declaration_and_and_framework_for_ ac/>. Acesso em: 15 ago. 2018.

PUZIOL, Jeinni Pereira; MOREIRA, Jani Alves da Silva. Capital humano e educação sob a perspectiva da UNESCO no Brasil. In: SEMINÁRIO NACIONAL DE ESTUDOS E PESQUISAS: HISTEDBR, 8., 2009, Campinas, SP. Anais... Campinas, SP: Unicamp, 2009. Disponível em: <http://www.histedbr.fe.unicamp. br/acer_histedbr/seminario/seminario8/_files/ p3bVDis.pdf>. Acesso em: 18 set. 2018.

RIZZINI, Irene. 0 século perdido: raízes históricas das políticas públicas para a Infância no Brasil. Rio de Janeiro: Petrobrás-BR/Ministério da Cultura/ USU/ Editora Universitária Amais, 1997.

RODRIGUES, Marilda Merência. Educação ao longo da vida: a eterna obsolescência humana. 2008. 182 f. Tese (Doutorado em Educação) - Programa de Pós-Graduação em Educação da Universidade Federal de Santa Catarina (UFSC), Florianópolis, 2008.

ROSEMBERG, Fúlvia (Org.). Creche. São Paulo: Cortez, 1989. (Coleção Temas em Destaque).

SAVIANI, D. A crise política no Brasil, o golpe e o papel da educação na resistência e na transformação. In: LUCENA, Carlos; PREVITALI, Fabiane Santana, LUCENA, Lurdes (Org.). A crise da democracia brasileira. Uberlândia, MG: Navegando, 2017. p. 215-232.

SHIROMA, E. O.; MORAES, M. C. M.; EVANGELISTA, O. Política educacional. 2. ed. Rio de Janeiro: DP\&A, 2002.

. Redes sociais e hegemonia: apontamentos para estudos de política educacional. In: AZEVEDO, Mário Luiz Neves de; LARA, Angela Mara de Barros (Org.). Políticas para a educação: análises e apontamentos. Maringá: Eduem, 2011. p. 15-38.

SoUZA, A. R. Reformas educacionais: descentralização, gestão e autonomia escolar. Educar, Curitiba, n. 22, p. 17-49, 2003.

A política educacional e seus objetos de estudo. Revista de Estudios Teóricos y Epistemológicos en Política Educativa, v. 1, n. 1, p. 75-89, ene./jun. 2016. 